\title{
RELATION OF BACTERIA TO DIATOMS IN SEA WATER*
}

\author{
By Selman A. Waksman, J. L. Stokes \\ and Margaret R. Butler \\ Woods Hole Oceanographic Institution
}

The functions of the two major constituent groups of the phytoplankton, namely, the diatoms and the bacteria, are supplementary to one another in the cycle of life in the sea: the diatoms synthesize organic matter from the simple chemical substances produced in the decomposition or mineralization of organic matter in the sea by the bacteria. Although the general aspects of the activities of these two groups of organisms are fairly well known, their mutual interrelationships still remain to be determined. The following studies were carried out in an attempt to elucidate this important problem.

\section{METHODS}

Four methods were used in these investigations: (I) Oxygen consumption in sea water enriched with diatom material; the oxygen being determined by a modification of the Winkler method. (2) Nitrogen transformation in the water, as a result of bacterial activities; the nitrogen being determined either directly as ammonia or indirectly, namely by an increase in oxygen consumption as a result of addition of glucose to the water; it had been previously found (Waksman \& Carey, I935) that the rate of glucose decomposition in sea water is controlled by the available nitrogen in the water. (3) Regeneration of the phosphorus, the latter being determined by the Atkins-Denigès method. (4) Increase in bacterial numbers, as measured by the plate method.

In most of the previous experiments on decomposition of organic matter in sea water (Waksman, Carey \& Reuszer, I933), excessive amounts of plankton material were added to the water. This resulted in appreciable changes in the aqueous medium, particularly the rapid consumption of the oxygen, whereby the system became changed from a purely aerobic to a distinctly anaerobic one. In the following experiments, mixed and pure plankton were added in concentrations not greatly in excess of those frequently found in natural sea water. Studies were also made of the transformation of marine plankton in the same vessel in which it had been synthesized.

* Contribution No. I57 of the Woods Hole Oceanographic Institution and Journal Series Paper, Department of Soil Microbiology, N.J. Agricultural Experiment Station. 


\section{Decomposition of Dead Diatom Material by Bacteria}

Two samples of diatom plankton consisting almost entirely of Rhizosolenia were collected in Vineyard Sound at Woods Hole. Analysed, on a dry basis, they gave 10.46 and $7.34 \%$ carbon, and $\mathrm{r} .52$ and $\mathrm{r} .05 \%$ nitrogen, giving respective $\mathrm{C}: \mathrm{N}$ ratios of 6.9 and $7 \cdot 0$; the phosphorus content of the mixed diatom material was $0.4 \mathrm{I} \%$, calculated as $\mathrm{PO}_{4}$. These samples were mixed carefully and used in some of the following experiments.

Five and ten mg. portions of this plankton, in an air-dry state, were placed in standard glass-stoppered oxygen bottles of approximately 220 c.c. capacity. The bottles were filled either with fresh, filtered sea water or with the same sea water enriched with Io mg. of glucose per litre. The bottles were then incubated in the dark under water at a temperature of $20-22^{\circ} \mathrm{C}$. The process of decomposition was followed by removing some of the bottles at different time intervals and analysing them for their oxygen, phosphate and bacterial content.

The results reported in Table I are typical of those obtained in several other experiments. In the sea water alone, the familiar sequence of a rapid bacterial multiplication, which in this instance reached a peak within 2 days, followed by a sharp drop to a low and fairly constant level, occurred (Waksman \& Carey, I935; Waksman \& Renn, 1936; Renn, 1937). Oxygen consumption was parallel with the increase in bacteria. Phosphate was also consumed during the logarithmic growth phase of bacterial multiplication; the lowest phosphate values coincided with the highest bacterial counts. However, as the bacterial cells began to die off and autolyse, phosphate was rapidly regenerated in the water. The increase of $20 \mathrm{mg}$. of $\mathrm{PO}_{4}$ per m. ${ }^{3}$ of sea water, at the end of $420 \mathrm{hr}$. of incubation, over the amount originally present, represents the phosphate liberated from the organic matter originally present in the sea water, either in true solution or suspension, and susceptible to bacterial attack.

In the water to which diatom material had been added, somewhat different results were obtained. Since the dead diatoms were an available food supply for the bacteria present in the water, a higher bacterial count was obtained than in the sea water alone. With $5 \mathrm{mg}$. of diatom material present, the maximum count of $\mathrm{I}, 440,000$ bacteria per I c.c. was obtained in $36 \mathrm{hr}$. With Io $\mathrm{mg}$. of diatom material present, the maximum number of bacteria was $2,000,000$ per I c.c. in $\mathrm{I} 2 \mathrm{hr}$. This indicates that the dead diatom material was quickly attacked and decomposed by the bacteria. The phosphate content of the sea water increased continuously throughout the duration of the experiment. Although some phosphate was no doubt utilized by the bacteria in the synthesis of their cell substance, there was more phosphate liberated from the diatom material by the bacteria than they could themselves assimilate. There resulted, therefore, a gradual increase in the $\mathrm{PO}_{4}$ content of the sea water. This inability of the bacteria to utilize all the phosphate that they had liber- 
ated was due to an insufficient supply of available energy which limited bacterial multiplication, as will be shown later. At the end of $420 \mathrm{hr}$. the minimum increase in phosphate content of the sea water was $66 \mathrm{mg}$. per $\mathrm{m}^{3}$, due to the decomposition of $5 \mathrm{mg}$. of the diatom material per bottle and to autolysis of the subsequently synthesized bacterial substance. When Io mg. of this material was used the phosphate increase was III mg. per $\mathrm{m}^{3}$ The amounts of phosphorus added in the diatom material were equivalent to 92.5 and $\mathrm{I}_{5} \mathrm{mg} . \mathrm{PO}_{4}$ per $\mathrm{m}^{3}$ respectively. It can thus be seen that approximately two-thirds of the total $\mathrm{PO}_{4}$ present in the diatom material was liberated into the sea water as a result of bacterial activities, within $420 \mathrm{hr}$. and usually within $\mathrm{I} 32 \mathrm{hr}$.

It is interesting to compare these results with those obtained by Cooper (I935), who found soluble phosphate to be liberated rapidly in the decomposition of plankton material, but less rapidly with diatom material than with animal plankton.

When an additional energy supply was added to the sea water, in the form of glucose, a marked increase in oxygen consumption, phosphate utilization and bacterial multiplication took place in sea water with and without the addition of $5 \mathrm{mg}$. of diatom material. The phosphate content of the water in both cases dropped within $\mathrm{I} 2 \mathrm{hr}$. to less than $30 \mathrm{mg}$. per $\mathrm{m}^{3}$, which is the lower limit of the analytical method. Regeneration of the phosphate did not occur until after $96 \mathrm{hr}$. of incubation when the bacterial numbers had been greatly reduced. That available nitrogen was liberated in the decomposition of the diatom material is best shown by the high bacterial count of $7,000,000$ per I c.c. in the presence of glucose.

Since all or practically all of the $\mathrm{PO}_{4}$ had been removed from the water in a very short time, in the presence of glucose, it was thought that it might be of interest to determine whether the lack of a sufficient supply of available $\mathrm{PO}_{4}$ was a limiting factor in the decomposition of the diatom material by the bacteria. In the following experiment an excess of $\mathrm{PO}_{4}$ was added to the sea water, and only $5 \mathrm{mg}$. portions of the diatom material were used. The results are reported in Table II. In the sea water alone and in the presence of diatom material, a consumption of $\mathrm{I} 88 \mathrm{mg}$. $\mathrm{PO}_{4}$ per $\mathrm{m}^{3}$ occurred within $60 \mathrm{hr}$. Within the same period of time, the sea water to which Io $\mathrm{mg}$. of glucose had been added showed a loss of $348 \mathrm{mg}$. of $\mathrm{PO}_{4}$ per $\mathrm{m}^{3}{ }^{3}$, whereas the sea water containing both diatom material and glucose showed a loss of $368 \mathrm{mg}$. $\mathrm{PO}_{4}$ per $\mathrm{m} .{ }^{3}$ After $60 \mathrm{hr}$. a gradual regeneration of the phosphate took place. The greatly increased rate of oxygen absorption and phosphate utilization seems to indicate that the diatoms decomposed more rapidly in the presence of an excess of phosphate.

The results of these two typical experiments are thus sufficient to demonstrate clearly that dead diatoms can serve as a readily available food supply for bacteria, the diatoms being rapidly decomposed and the nitrogen and phosphorus rapidly liberated in available forms. 
Table I. Decomposition of Dead Diatom Material in Sea Water by Bacteria

\begin{tabular}{|c|c|c|c|c|c|c|c|c|c|c|c|c|c|c|c|}
\hline \multirow[b]{2}{*}{$\begin{array}{l}\text { Incuba- } \\
\text { tion } \\
\text { hours }\end{array}$} & \multicolumn{3}{|c|}{ Sea water alone } & \multicolumn{3}{|c|}{$\begin{array}{l}\text { Diatom material } \\
5 \mathrm{mg} .\end{array}$} & \multicolumn{3}{|c|}{$\begin{array}{l}\text { Diatom material } \\
\text { Io mg. }\end{array}$} & \multicolumn{3}{|c|}{$\begin{array}{l}\text { Glucose } \\
\text { Io mg. }\end{array}$} & \multicolumn{3}{|c|}{$\begin{array}{l}\text { Glucose ro mg. + } \\
\text { diatom material } 5 \mathrm{mg} \text {. }\end{array}$} \\
\hline & $\begin{array}{l}\text { Oxygen } \\
\text { con- } \\
\text { sumed } \\
\text { c.c. } / 1 \text {. }\end{array}$ & $\begin{array}{c}\mathrm{PO}_{4} \\
\gamma / 1 .\end{array}$ & $\begin{array}{l}\text { Bacteria } \\
\text { in } \\
\text { I c.c. }\end{array}$ & $\begin{array}{l}\text { Oxygen } \\
\text { con- } \\
\text { sumed } \\
\text { c.c. } / 1 \text {. }\end{array}$ & $\begin{array}{l}\mathrm{PO}_{4} \\
\gamma / 1 .\end{array}$ & $\begin{array}{l}\text { Bacteria } \\
\text { in } \\
\text { I c.c. }\end{array}$ & $\begin{array}{c}\text { Oxygen } \\
\text { con- } \\
\text { sumed } \\
\text { c.c. } / 1 \text {. }\end{array}$ & $\begin{array}{l}\mathrm{PO}_{4} \\
\gamma / 1 .\end{array}$ & $\begin{array}{l}\text { Bacteria } \\
\text { in } \\
\text { I c.c. }\end{array}$ & $\begin{array}{c}\text { Oxygen } \\
\text { con- } \\
\text { sumed } \\
\text { c.c. } / 1 .\end{array}$ & $\begin{array}{c}\mathrm{PO}_{4} \\
\gamma / 1 .\end{array}$ & $\begin{array}{l}\text { Bacteria } \\
\text { in } \\
\text { I c.c. }\end{array}$ & $\begin{array}{l}\text { Oxygen } \\
\text { con- } \\
\text { sumed } \\
\text { c.c. } / 1 .\end{array}$ & $\begin{array}{c}\mathrm{PO}_{4} \\
\gamma / 1 .\end{array}$ & $\begin{array}{l}\text { Bacteria } \\
\text { in } \\
\mathbf{x} \text { c.c. }\end{array}$ \\
\hline 0 & 0 & 126 & 10,400 & 0 & 126 & Io,400 & 0 & 126 & 10,400 & 0 & 126 & I0,400 & 0 & 126 & 10,400 \\
\hline 12 & 0.04 & I3I & 690,000 & 0.50 & I35 & I,4I0,000 & 0.78 & I47 & $2,000,000$ & 0.62 & $<30$ & 470,000 & $\mathrm{I} \cdot \mathrm{O} 2$ & $<30$ & $2,200,000$ \\
\hline 24 & 0.15 & 128 & 770,000 & 0.67 & I 43 & 900,000 & I. 35 & I49 & $\mathrm{I}, 290,000$ & 2.66 & $<30$ & $2,180,000$ & 3.40 & $<30$ & $7,600,000$ \\
\hline 36 & 0.19 & 98 & 850,000 & 0.90 & I49 & $1,440,000$ & $I \cdot 4 \mathrm{I}$ & - & $\mathrm{I}, 3 \mathrm{IO}, 000$ & 3.69 & $<30$ & $2,170,000$ & $4 \cdot 32$ & $<30$ & $5,200,000$ \\
\hline 48 & 0.33 & - & - & $\mathrm{I} \cdot \mathrm{O} 2$ & - & & $I \cdot 72$ & - & - & 3.98 & - & & 4.66 & - & \\
\hline 60 & 0.38 & I35 & 600,000 & $I \cdot 05$ & I48 & $\mathrm{I}, \mathrm{I} 5 \mathrm{O}, 000$ & I. 96 & I73 & 750,000 & $4 \cdot 20$ & $<30$ & 730,000 & 4.97 & $<30$ & $\mathrm{I}, 860,000$ \\
\hline 96 & 0.50 & & - & I. 59 & I7I & 61,000 & $2 \cdot 56$ & 192 & I 42,000 & 5.69 & 64 & 35,000 & 5.74 & 82 & 260,000 \\
\hline 132 & 0.78 & I44 & 6,100 & I.92 & 209 & & $2 \cdot 66$ & 244 & I09,000 & $5 \cdot 80^{\star}$ & II 8 & & - & 165 & I 24,000 \\
\hline 252 & - & - & 3,100 & $2 \cdot 26$ & 一 & 28,000 & 3.83 & - & 60,000 & - & I49 & 1,500 & 一 & - & 100,000 \\
\hline 420 & $I \cdot 72$ & I46 & $\mathrm{I}, 800$ & 2.60 & 212 & 12,700 & 4.66 & 257 & 24,000 & - & -49 & 2,100 & - & - & 17,800 \\
\hline
\end{tabular}

Table II. Influence of Available Phosphorus upon Decomposition of Dead Diatom Material

\begin{tabular}{|c|c|c|c|c|c|c|c|c|c|c|c|c|}
\hline \multirow[b]{2}{*}{$\begin{array}{l}\text { Incuba- } \\
\text { tion } \\
\text { hours }\end{array}$} & \multicolumn{3}{|c|}{ Sea water alone } & \multicolumn{3}{|c|}{ Diatom material $5 \mathrm{mg}$. } & \multicolumn{3}{|c|}{ Glucose ro mg. } & \multicolumn{3}{|c|}{$\begin{array}{l}\text { Glucose Io mg. + } \\
\text { diatom material } 5 \mathrm{mg} \text {. }\end{array}$} \\
\hline & $\begin{array}{l}\text { Oxygen } \\
\text { con- } \\
\text { sumed } \\
\text { c.c. } / 1 .\end{array}$ & $\begin{array}{l}\mathrm{PO}_{4} \\
\gamma / 1\end{array}$ & $\begin{array}{l}\text { Bacteria } \\
\text { in I c.c. }\end{array}$ & $\begin{array}{l}\text { Oxygen } \\
\text { con- } \\
\text { sumed } \\
\text { c.c. } / 1 .\end{array}$ & $\begin{array}{l}\mathrm{PO}_{4} \\
\gamma / 1 .\end{array}$ & $\begin{array}{l}\text { Bacteria } \\
\text { in I c.c. }\end{array}$ & $\begin{array}{l}\text { Oxygen } \\
\text { con- } \\
\text { sumed } \\
\text { c.c. } / 1 \text {. }\end{array}$ & $\begin{array}{l}\mathrm{PO}_{4} \\
\gamma / 1\end{array}$ & $\begin{array}{l}\text { Bacteria } \\
\text { in I c.c. }\end{array}$ & $\begin{array}{l}\text { Oxygen } \\
\text { con- } \\
\text { sumed } \\
\text { c.c. } / 1 \text {. }\end{array}$ & $\begin{array}{l}\mathrm{PO}_{4} \\
\gamma / 1 .\end{array}$ & $\begin{array}{l}\text { Bacteria } \\
\text { in I c.c. }\end{array}$ \\
\hline 0 & $\circ$ & I,404 & 550 & o & I,404 & 550 & $\circ$ & I,404 & 550 & 0 & $I, 404$ & 550 \\
\hline I6 & 0.37 & 1,388 & 42,000 & 0.53 & $\mathrm{I}, 384$ & 730,000 & 0.37 & $\mathrm{I}, 400$ & 86,000 & 0.70 & I, 400 & 620,000 \\
\hline 24 & 0.65 & - & 77,000 & $\mathrm{I} .02$ & & 550,000 & $I \cdot 16$ & 1,328 & 590,000 & $2 \cdot 30$ & $\mathrm{I}, 304$ & $5,300,000$ \\
\hline 36 & 0.82 & 1,392 & I IO, , O0 & $I \cdot 28$ & 1,340 & $1,460,000$ & 3.04 & I, 248 & I,I IO,OOO & 3.73 & $\mathrm{I}, \mathrm{I} 92$ & 5700,000 \\
\hline 60 & 1.02 & I,2I6 & 147,000 & I. 74 & I, 216 & 630,000 & $4 \cdot 24$ & I, 056 & $1,690,000$ & $5 \cdot 15$ & $\mathrm{I}, 036$ & $6,000,000$ \\
\hline IO8 & I.38 & I,3I6 & $4 \mathrm{I}, 000$ & $2 \cdot 33$ & 1,376 & - & $5 \cdot 38^{\star}$ & $\mathrm{I}, \mathrm{I} 28$ & 640,000 & - & I, 288 & $\mathrm{I}, 000,000$ \\
\hline 264 & 2.02 & 1,448 & 9,800 & 3.33 & 1,392 & 42,000 & - & 1,336 & I74,000 & - & $\mathrm{r}, 448$ & 188,000 \\
\hline
\end{tabular}




\section{RELATIONSHiP OF BACteria to LIVING Diatoms}

In these investigations diatom cultures containing bacteria, bacteria-free diatom cultures and freshly collected mixed diatom plankton were used.

A culture of Nitzschia closterium originally obtained from Dr E. J. Allen, of the Plymouth Laboratory, was grown on the standard nutrient Miquel-Allen medium, in 500 c.c. Erlenmeyer flasks, for a period of 20-30 days. The contents of several flasks were combined, centrifuged and washed with fresh sea water, again centrifuged and the residue suspended in sea water. Varying amounts of the diatom suspension were added to 220 c.c. oxygen bottles containing fresh sea water. The bottles were incubated in the dark, at room temperature under water, and analysed at various intervals. The bacterial content of I c.c. of the concentrated Nitzschia material was $4,800,000$ and the diatom content $18,400,000$; the fresh sea water contained 12,000 bacteria in I c.c. The results presented in Table III show that the Nitzschia cells added to fresh sea water underwent a certain amount of oxidation; this was accom-

\section{Table III. Relation of Bacteria to Enriched Culture of Nitzschia CLOSTERIUM ADDED TO SEA WATER}

\begin{tabular}{|c|c|c|c|c|c|c|c|c|c|}
\hline \multirow{2}{*}{$\begin{array}{l}\text { Nitzschia } \\
\text { culture } \\
\text { added } \\
\text { per litre } \\
\text { c.c. }\end{array}$} & \multicolumn{4}{|c|}{$\begin{array}{l}\text { Oxygen consumed } \\
\text { c.c. per litre }\end{array}$} & \multicolumn{3}{|c|}{ Bacteria in I c.c. } & \multicolumn{2}{|c|}{$\begin{array}{l}\text { Phosphate } \\
\gamma \text { per litre }\end{array}$} \\
\hline & $\begin{array}{c}\text { I } \\
\text { day }\end{array}$ & days & $\begin{array}{c}6 \\
\text { days }\end{array}$ & $\begin{array}{c}8 \\
\text { days }\end{array}$ & $\begin{array}{l}\text { I } \\
\text { day }\end{array}$ & days & $\stackrel{8}{\text { days }}$ & $\begin{array}{c}6 \\
\text { days }\end{array}$ & $\begin{array}{c}8 \\
\text { days }\end{array}$ \\
\hline 0 & 0.48 & 0.69 & 0.90 & - & 850,000 & 750,000 & 30,000 & 70 & - \\
\hline $2 \cdot 3$ & 0.66 & $2 \cdot 19$ & $2 \cdot 79$ & 3.39 & 690,000 & 575,000 & 46,000 & I IO & 210 \\
\hline $4 \cdot 5$ & $0.8 \mathrm{I}$ & 2.52 & $5 \cdot 16$ & $5.22 \dagger$ & 800,000 & $2,750,000$ & 76,000 & 420 & 380 \\
\hline $9 \cdot 0$ & $\mathrm{I} \cdot 05$ & $2 \cdot 34$ & $5.22 \dagger$ & $5 \cdot 22 t$ & 650,000 & 405,000 & 825,000 & 300 & 680 \\
\hline
\end{tabular}

* The dry matter content in the Nitzschia suspension was calculated from the total nitrogen (O. I4 mg. per I c.c.) to be equivalent to I mg. organic carbon in I c.c.

$\dagger$ Oxygen used up completely.

panied by the liberation of phosphate, but not by an appreciable increase in bacterial numbers. The increased consumption of the oxygen may have been due partly to the respiration of the diatoms and partly to bacterial decomposition. Maximum bacterial multiplication and phosphate liberation were obtained after 8 days, with the highest concentration of the Nitzschia cells. At this stage, practically all the phosphate present in the Nitzschia material had been regenerated, as is easily calculated from the $\mathrm{N} / \mathrm{PO}_{4}$ ratio of $7 / 3$; this ratio was found for the mixed diatom plankton. Dr H. W. Harvey $\ddagger$ has suggested that it is quite possible for some of the phosphate to be introduced as precipitated ferric phosphate with the Nitzschia culture, which would account in part for the high phosphate recovery.

This experiment was repeated, using younger (I2-day-old) cultures of the diatom material and concentrating it by centrifuging, to give a preparation

‡ Personal communication. 
which contained 9,200,000 Nitzschia and 3,100,000 bacteria per I c.c. The results of this experiment (Table IV) confirmed the previous observation that, in the presence of a living culture of Nitzschia, the bacterial activities were very limited. No nitrogen was liberated, as shown by the fact that the addition of glucose to the cultures brought about no increase in oxygen consumption: with 2.3 c.c. Nitzschia suspension added per litre of water, the increase in oxygen consumption was, without glucose, 0.87 c.c. and with glucose 0.72 c.c.; with 4.5 c.c. of the diatom culture, the corresponding increases were 2.10 and I.29 c.c. respectively. The addition of nitrate to the water did not stimulate to any great extent the destruction of the diatoms.

In order to eliminate the interfering factor which might have resulted from the introduction into the fresh sea water of large numbers of bacteria, and also for the purpose of determining the consumption of oxygen as a result of diatom respiration, bacteria-free cultures of the diatom were used.

\section{Table IV. Influence of Nitrogen and Glucose on the OXIDATION OF NITZSCHIA CLOSTERIUM}

\begin{tabular}{|c|c|c|c|c|c|c|c|c|}
\hline \multirow{2}{*}{$\begin{array}{l}\text { Nitzschia } \\
\text { culture } \\
\text { added } \\
\text { per litre } \\
\text { c.c. }\end{array}$} & \multirow{2}{*}{$\begin{array}{l}\text { Nitrate } \\
\text { nitrogen } \\
\text { added } \\
\text { per litre } \\
\text { mg. }\end{array}$} & \multirow{2}{*}{$\begin{array}{c}\text { Glucose } \\
\text { added } \\
\text { per } \\
\text { litre } \\
\text { mg. }\end{array}$} & \multicolumn{3}{|c|}{$\begin{array}{l}\text { Oxygen consumed } \\
\text { c.c. per litre }\end{array}$} & \multicolumn{2}{|c|}{$\begin{array}{l}\text { Nitrate } \mathrm{N} \\
\text { mg. per litre }\end{array}$} & \multirow{2}{*}{$\underbrace{\begin{array}{l}\text { Bacteria } \\
\text { in I c.c. }\end{array}}_{6 \text { days }}$} \\
\hline & & & 2 days & 6 days & Io days & 2 days & 6 days & \\
\hline 0 & 0 & 0 & 0.39 & 0.63 & 0.78 & 0.01 & 0.01 & 12,000 \\
\hline $2 \cdot 3$ & 0 & 0 & 0.63 & $\mathrm{I} \cdot 20$ & $I \cdot 65$ & 0.01 & 0.01 & I8,०00 \\
\hline $4 \cdot 5$ & 0 & 0 & $0.8 \mathrm{I}$ & I. 56 & $2 \cdot 88$ & 0.01 & $0.0 I$ & I9,000 \\
\hline 9.0 & 0 & 0 & I.05 & $3 \cdot 45$ & $5 \cdot 16^{\star}$ & 0.01 & Trace & 450,000 \\
\hline 0 & 0.07 & 0 & 0.45 & 0.69 & 0.69 & 0.10 & $0 \cdot 10$ & - \\
\hline $4 \cdot 5$ & 0.07 & 0 & 0.93 & 2.01 & $2 \cdot 85$ & 0.01 & Trace & - \\
\hline 9.0 & 0.07 & 0 & $\mathrm{I} \cdot 47$ & $3.8 \mathrm{I}$ & $4 \cdot 62$ & 0.01 & Trace & - \\
\hline 0 & 0 & 5 & 0.63 & 1.62 & $2 \cdot 52$ & - & - & 55,000 \\
\hline $2 \cdot 3$ & 0 & 5 & 0.69 & $2 \cdot 16$ & $3 \cdot 24$ & - & - & 70,000 \\
\hline $4 \cdot 5$ & 0 & 5 & 0.63 & $2 \cdot 34$ & $3 \cdot 8 \mathrm{I}$ & - & - & 330,000 \\
\hline
\end{tabular}

A culture of Nitzschia closterium was obtained from Dr C. B. van Niel. It was grown for 13 days in Miquel solution, centrifuged and washed with fresh sterile sea water under sterile conditions and resuspended in sterile sea water. There were 8,500,000 diatom cells in I c.c. of suspension. One-half and 2 c.c. portions of this suspension were placed in oxygen bottles and filled with paper filtered sea water, previously kept overnight in the laboratory. In order to determine the oxygen consumption due to the respiration of the diatoms, controls containing the same amounts of diatom suspension were placed in sterile oxygen bottles, and filled with sea water which had been previously sterilized by heating at $15 \mathrm{lb}$. pressure for $20 \mathrm{~min}$. The oxygen content of the sterile sea water was less than that of the fresh sea water due to the difficulty encountered in resaturating the water with oxygen after sterilization. All the bottles were placed in the dark under water and analyses made at different intervals. The results given in Table V show that during the first $88 \mathrm{hr}$. of 
incubation the excess oxygen consumption in the sea water containing 2 c.c. diatom suspension over the oxygen consumption in the sea water alone can be accounted for by the respiration of the diatoms, since the sea water plus 2 c.c. diatom suspension consumed I.8I c.c. oxygen per litre and the sea water alone I. 53 c.c. per litre, while the consumption of oxygen in the sterilized sea water plus 2 c.c. diatom suspension was 0.35 c.c. per litre. By adding the latter two figures, a consumption of I.88 c.c. oxygen per litre is obtained; this is very close to the I.8I c.c. oxygen consumed in the fresh sea water to which the diatom suspension had been added.

A microscopic examination of the centrifuged sediment at this point revealed that the diatoms were in all cases in good physical condition (chromatophores intact). It may therefore be concluded that living diatoms are not attacked by the bacteria. However, the bacterial counts showed that a greater

Table V. Relationship between Pure Cultures of LIVING DiATOMS AND BACTERIA

\begin{tabular}{|c|c|c|c|c|c|c|c|c|}
\hline \multirow[b]{2}{*}{$\begin{array}{l}\text { Incuba- } \\
\text { tion } \\
\text { hours }\end{array}$} & \multicolumn{2}{|c|}{ Fresh sea water } & \multicolumn{2}{|c|}{$\begin{array}{c}\text { Fresh sea water } \\
+0.5 \text { c.c. } \\
\text { diatom culture }\end{array}$} & \multicolumn{2}{|c|}{$\begin{array}{c}\text { Fresh sea water } \\
+2 \text { c.c. } \\
\text { diatom culture }\end{array}$} & $\begin{array}{l}\text { Sterile } \\
\text { sea } \\
\text { water }+ \\
0.5 \mathrm{c} . \mathrm{c} . \\
\text { diatom }\end{array}$ & $\begin{array}{c}\text { Sterile } \\
\text { sea } \\
\text { water }+ \\
2 \text { c.c. } \\
\text { diatom }\end{array}$ \\
\hline & $\begin{array}{l}\text { Oxygen } \\
\text { con- } \\
\text { sumed } \\
\text { c.c. } 1 .\end{array}$ & $\begin{array}{l}\text { Bacteria } \\
\text { in I c.c. }\end{array}$ & $\begin{array}{l}\text { Oxygen } \\
\text { con- } \\
\text { sumed } \\
\text { c.c. } 1 .\end{array}$ & $\begin{array}{l}\text { Bacteria } \\
\text { in I c.c. }\end{array}$ & $\begin{array}{l}\text { Oxygen } \\
\text { con- } \\
\text { sumed } \\
\text { c.c. } 1 \text {. }\end{array}$ & $\begin{array}{l}\text { Bacteria } \\
\text { in I c.c. }\end{array}$ & $\begin{array}{l}\text { Oxygen } \\
\text { con- } \\
\text { sumed } \\
\text { c.c. } / 1 \text {. }\end{array}$ & $\begin{array}{l}\text { Oxygen } \\
\text { con- } \\
\text { sumed } \\
\text { c.c. } / 1 \text {. }\end{array}$ \\
\hline 0 & 0 & 400 & 0 & 400 & 0 & 400 & 0 & o \\
\hline 20 & 0.34 & $\mathrm{I}, 000$ & 0.40 & I85,000 & 0.74 & 10,000 & 0.06 & - \\
\hline 42 & 0.80 & 39,000 & 0.80 & I 33,000 & $\mathrm{I} \cdot 03$ & 312,000 & 0.14 & 0.34 \\
\hline 88 & I. 53 & - & I. 55 & - & $\mathrm{I} \cdot 8 \mathrm{I}$ & & 0.17 & 0.35 \\
\hline I36 & $I \cdot 84$ & $74, \infty 00$ & $2 \cdot 18$ & 8I, & $2 \cdot 74$ & 98,000 & $0.23^{\star}$ & $0.46^{\star}$ \\
\hline I 84 & $2 \cdot 10$ & 77,000 & $2 \cdot 42$ & I 58,000 & 2.96 & 107,000 & $0.46^{\star}$ & $0.55^{\star}$ \\
\hline $\begin{array}{c}256 \\
20 \text { days }\end{array}$ & - & - & - & - & - & - & $\mathrm{I} \cdot 03^{\star}$ & $I \cdot 03^{\star}$ \\
\hline 20 days & $2 \cdot 33$ & 900 & $2 \cdot 99$ & 3,700 & 3.69 & 9,200 & - & 一 \\
\hline
\end{tabular}

development of bacteria took place in the presence of the diatoms than in their absence. This confirms the previous observations of Gran (I933) that there is a certain parallelism between the development of diatoms and bacteria in sea water.

After $136 \mathrm{hr}$. incubation, an examination of the centrifuged sediment showed that the diatoms in the unsterilized sea water were badly disintegrated. The chromatophores were completely gone in many cases, and the cells were difficult to see because of changes in refractive index due to death. A number of Protozoa were found to be present in the water. The bacterial numbers showed a decreasing population, with the exception of the untreated sea water in which the peak had not yet been reached. Unfortunately, at this point, the sterile sea water to which the diatom culture had been added became contaminated with bacteria.

A comparative study was now made of the relationship of bacteria to living 
and dead diatoms added to fresh sea water. Two series of oxygen bottles, one with and one without $5 \mathrm{mg}$. glucose per litre, received sea water enriched with $\mathrm{PO}_{4}$ (I00 mg. per m. ${ }^{3}$ ). Each series was divided into three sets: (I) sea water alone; (2) 2 c.c. of a concentrated suspension of living Nitzschia (I6,000,000 diatoms per I c.c. of suspension); (3) the same amount of diatom material, heated at $60-62^{\circ} \mathrm{C}$. for $45 \mathrm{~min}$. in order to kill the diatoms.

The results presented in Table VI show that the living diatoms and not the bacteria were the agents responsible for the rapid phosphate consumption. This is definitely demonstrated by the fact that the control sea water having, after I day, a higher bacterial count than the sea water with the 2 c.c. of living diatoms, showed a $\mathrm{PO}_{4}$ consumption of only $28 \mathrm{mg}$. per m. ${ }^{3}$, as compared with the complete or almost complete consumption of the $298 \mathrm{mg}$. of $\mathrm{PO}_{4}$ in the sea water with the living diatoms. This fact is even more sharply brought out in the water containing glucose. In spite of the presence of glucose, which so readily stimulates bacterial multiplication, the bacterial count in the sea water plus living diatoms remained relatively low, while the phosphate and oxygen were rapidly consumed. Living diatoms can therefore be considered as successful competitors of bacteria for the available nutrients, and may represent one of the factors which tend to limit bacterial multiplication in the sea. The process of initial phosphate utilization and subsequent regeneration is again clearly indicated. On the 5 th day, a sharp increase was found in the number of bacteria in the water receiving living diatoms. A microscopic examination of the centrifuged material showed that the diatoms had disintegrated in large measure. The bacterial increase was therefore due to the decomposition of the dead diatoms.

\section{Relationship of Bacteria to Fresh Marine Plankton}

Five samples of plankton were obtained by means of a No. 20 silk net on August 3-4 1936, one at a station in Nantucket Sound (No. I) and four at stations on George's Bank (Nos. 2-5). The plankton was washed free from sedimentary material, using fresh sea water. It was then allowed to settle and concentrated plankton thus obtained. Different amounts of the freshly collected samples of plankton were added to a series of oxygen bottles containing fresh sea water obtained from the same stations. The bottles were incubated in the dark, and analysed for oxygen, bacterial numbers and phosphate. Sample No. I contained I0,536 diatoms per I c.c., mostly Chaetoceras, Skeletonema and Rhizosolenia; sample No. 2, 3,I59 diatoms, mostly Rhizosolenia; No. 3, 19,025, No. 4, 24,450, and No. 5, I6,925, mostly Rhizosolenia and Nitzschia. The plankton of the last three stations consisted almost entirely of diatoms. The carbon content of the plankton was calculated from the nitrogen content using the ratio of $\mathrm{C}: \mathrm{N}=7: \mathrm{I}$. The results presented in Table VII show that considerable oxygen consumption took place in all cases; the phosphate was liberated in a soluble form. These processes were not 
Table VI. Relationship between Bacteria, and Living and Dead Diatoms in Sea Water

Ioo $\gamma \mathrm{PO}_{4}$ added per litre

\begin{tabular}{|c|c|c|c|c|c|c|c|c|c|}
\hline \multirow[b]{2}{*}{$\begin{array}{l}\text { Incuba- } \\
\text { tion } \\
\text { days }\end{array}$} & \multicolumn{3}{|c|}{ Sea water alone } & \multicolumn{3}{|c|}{ Living diatoms ${ }^{\star}$} & \multicolumn{3}{|c|}{ Dead diatoms* } \\
\hline & $\begin{array}{l}\text { Oxygen } \\
\text { consumed } \\
\text { c.c. } / 1 .\end{array}$ & $\begin{array}{c}\mathrm{PO}_{4} \\
\gamma / 1 .\end{array}$ & $\begin{array}{l}\text { Bacteria } \\
\text { in I c.c. }\end{array}$ & $\begin{array}{l}\text { Oxygen } \\
\text { consumed } \\
\text { c.c. } / 1 \text {. }\end{array}$ & $\begin{array}{c}\mathrm{PO}_{4} \\
\gamma / 1 .\end{array}$ & $\begin{array}{l}\text { Bacteria } \\
\text { in I c.c. }\end{array}$ & $\begin{array}{l}\text { Oxygen } \\
\text { consumed } \\
\text { c.c. } / 1 \text {. }\end{array}$ & $\begin{array}{c}\mathrm{PO}_{4} \\
\gamma / 1 .\end{array}$ & $\begin{array}{l}\text { Bacteria } \\
\text { in I c.c. }\end{array}$ \\
\hline 0 & 0 & 298 & 400 & o & 298 & 400 & o & 298 & 400 \\
\hline I & 0.14 & 270 & I 84,000 & 0.40 & $<30$ & I I 7,000 & 0.94 & 270 & 430,000 \\
\hline 3 & 0.57 & 282 & 5,000 & 0.97 & $<30$ & I90,000 & $I \cdot 20$ & 280 & 20,000 \\
\hline 5 & 0.62 & 298 & 20,000 & $I \cdot 42$ & 185 & 70,000 & I'93 & 3 I4 & I 8,000 \\
\hline 7 & 0.80 & 301 & 5,700 & $\mathrm{I} \cdot 77$ & 319 & 26,000 & 2.II & 338 & I I ,700 \\
\hline
\end{tabular}

5 mg. glucose and $100 \gamma \mathrm{PO}_{4}$ per litre

\begin{tabular}{|c|c|c|c|c|c|c|c|c|}
\hline \multicolumn{3}{|c|}{ Sea water alone } & \multicolumn{3}{|c|}{ Living diatoms* } & \multicolumn{3}{|c|}{ Dead diatoms* } \\
\hline $\begin{array}{l}\text { Oxygen } \\
\text { consumed } \\
\text { c.c. } / 1 .\end{array}$ & $\begin{array}{c}\mathrm{PO}_{4} \\
\gamma / 1 .\end{array}$ & $\begin{array}{l}\text { Bacteria } \\
\text { in I c.c. }\end{array}$ & $\begin{array}{c}\text { Oxygen } \\
\text { consumed } \\
\text { c.c. } / 1 \text {. }\end{array}$ & $\begin{array}{c}\mathrm{PO}_{4} \\
\gamma / 1 .\end{array}$ & $\begin{array}{l}\text { Bacteria } \\
\text { in I c.c. }\end{array}$ & $\begin{array}{c}\text { Oxygen } \\
\text { consumed } \\
\text { c.c./1. }\end{array}$ & $\begin{array}{l}\mathrm{PO}_{4} \\
\gamma / 1 .\end{array}$ & $\begin{array}{l}\text { Bacteria } \\
\text { in I c.c. }\end{array}$ \\
\hline 0 & 298 & 400 & 0 & 298 & 400 & 0 & 298 & 400 \\
\hline$I \cdot 7 I$ & $<30$ & $2,080,000$ & 0.77 & $<30$ & 52,000 & I·99 & $<30$ & 710,000 \\
\hline $2 \cdot 63$ & 170 & 8,000 & 2.05 & $<30$ & 35,000 & $3 \cdot 76$ & 167 & 90,000 \\
\hline $3 \cdot 36$ & 203 & 5,000 & $3 \cdot 26$ & $<30$ & I $4 \mathrm{I}, 000$ & $4: 39$ & 258 & 51,000 \\
\hline 3.53 & 237 & I I, OOO & 3.93 & 94 & I 58,000 & $4 \cdot 79$ & 256 & 8,500 \\
\hline
\end{tabular}

* 2 c.c. of concentrated diatom culture, containing 16,000,000 Nitzschia cells in I c.c. 
always accompanied by corresponding increases in bacterial numbers, especially in the diatom-rich plankton. With the exception of Station 3, there was a certain parallelism between the concentration of the plankton in the samples and the rate of oxygen consumption. The plankton of Station I and to some extent of Station 2 was rich in copepods, which may account for the greater abundance of bacteria in the water receiving these two samples of plankton. The most significant result of this experiment is the lack of correlation between oxygen consumption in the water receiving diatoms and bacterial multiplication.

TABle VII. RElation of Bacteria to Freshly Collected Mixed Diatom Plankton

\begin{tabular}{|c|c|c|c|c|c|c|c|c|c|}
\hline \multirow{2}{*}{$\begin{array}{l}\text { Station } \\
\text { no. }\end{array}$} & \multirow{2}{*}{$\begin{array}{c}\text { Plank- } \\
\text { ton } \\
\text { added } \\
\text { per } \\
\text { litre } \\
\text { c.c. }{ }^{\star}\end{array}$} & \multicolumn{3}{|c|}{$\begin{array}{l}\text { Oxygen consumed } \\
\text { c.c. per litre }\end{array}$} & \multicolumn{4}{|c|}{ Bacteria in I c.c. } & \multirow{2}{*}{$\begin{array}{l}\text { Phos- } \\
\text { phate } \\
\gamma \text { per } \\
\text { litre } \\
7 \text { days }\end{array}$} \\
\hline & & I dayt & 3 days & 7 days & Start & I day & 3 days & 7 days & \\
\hline I & 0 & 0.78 & - & - & 20,100 & I, I60,000 & - & 28,000 & 30 \\
\hline I & $4 \cdot 5$ & 0.88 & I. $4 \mathrm{I}$ & I. 77 & 32,200 & $2,170,000$ & 49,000 & $2 \mathrm{I}, \mathrm{000}$ & 40 \\
\hline I & 9.0 & $\mathrm{I} \cdot \mathrm{I} 4$ & $\mathrm{I} \cdot 53$ & $\mathrm{I} \cdot 89$ & - & $2,250,000$ & 72,000 & 25,500 & 40 \\
\hline I & $22 \cdot 5$ & $I \cdot I 8$ & $\mathrm{I} \cdot 77$ & $\mathrm{I} \cdot 98$ & - & $2,450,000$ & 81,000 & 22,000 & 120 \\
\hline 2 & 0 & $0.5 \mathrm{I}$ & - & 0.83 & 5,800 & 279,000 & - & 46,500 & 40 \\
\hline 2 & $4 \cdot 5$ & 0.48 & 0.99 & $I \cdot 25$ & 7,200 & 307,000 & 75,000 & 72,000 & 60 \\
\hline 2 & $9 \cdot 0$ & 0.62 & $I \cdot 35$ & $I \cdot 79$ & - & 740,000 & I3 I, OOO & 52,500 & 50 \\
\hline 2 & $22 \cdot 5$ & $I \cdot 29$ & 2.97 & $3 \cdot 77$ & - & $2,030,000$ & 270,000 & 39,000 & I 50 \\
\hline 3 & 0 & 0.42 & - & 0.99 & 4,200 & $\mathrm{I}, 050,000$ & - & 62,000 & 50 \\
\hline 3 & 4.5 & $0.6 \mathrm{I}$ & $\mathrm{I} \cdot 03$ & $I \cdot 65$ & 24,000 & 915,000 & 240,000 & 57,500 & 80 \\
\hline 3 & $9 \cdot 0$ & 0.65 & $\mathrm{I} \cdot 7 \mathrm{I}$ & $\mathrm{I} \cdot 74$ & - & 990,000 & 375,000 & 59,500 & 90 \\
\hline 4 & 0 & 0.39 & - & 0.90 & 12,400 & 940,000 & - & 38,500 & 70 \\
\hline 4 & 4.5 & 0.75 & $\mathrm{I} \cdot 38$ & I. 98 & 9,500 & - & 355,000 & 65,000 & 80 \\
\hline 4 & 9.0 & $0.9 \mathrm{I}$ & $2 \cdot 14$ & $3 \cdot 15$ & - & 980,000 & 245,000 & & - \\
\hline 5 & 0 & 0.31 & - & 0.84 & 2,700 & 550,000 & - & I09,000 & 30 \\
\hline 5 & $4 \cdot 5$ & 0.54 & $\mathrm{I} \cdot 7 \mathrm{I}$ & $2 \cdot 88$ & 6,600 & 790,000 & 330,000 & 56,000 & IOO \\
\hline 5 & $9 \cdot 0$ & 0.57 & $2 \cdot 75$ & 5.01 & - & $\mathrm{I}, 720,000$ & 365,000 & $5 \mathrm{I}, 000$ & 120 \\
\hline
\end{tabular}

* The carbon content of I c.c. of the five samples of plankton were as follows: No. I, $0.05 \mathrm{mg}$; No. 2, $0.06 \mathrm{mg}$; No. 3, 0.37 mg.; No. 4, $0.22 \mathrm{mg}$; No. 5, 0.23 mg.

$\dagger 42$ hr. for Station I.

\section{Relation of Bacteria to Freshly Synthesized Diatom Material}

It has been shown previously (Waksman \& Renn, I936) that the processes resulting from diatom oxidation in sea water could be better elucidated, if growth of the diatoms was first permitted to take place in closed containers, and photosynthesis then stopped by placing the containers in the dark. Conditions are thus obtained which approach more nearly those found in nature. In order to increase the amount of synthesized diatom material above that normally present in sea water, an enriched medium was employed. This consisted of fresh sea water, to which $5 \mathrm{mg}$. $\mathrm{KNO}_{3}, 2 \mathrm{mg} . \mathrm{K}_{2} \mathrm{HPO}_{4}$ and $2 \mathrm{mg}$. $\mathrm{FeCl}_{3}$ had been added per litre. The enriched water was distributed in glass-stoppered oxygen bottles, and these incubated at room temperature, under water and in the light, in glass aquaria. After different periods, a few of 
the bottles were removed. Some were analysed at once and some were transferred to a water bath kept dark at room temperature, and allowed to remain under water for 5-I2 days. In those bottles, where extensive photosynthesis took place, the water became supersaturated with oxygen, some of which being liberated in a gaseous form, was lost, thus modifying the results of some of the oxygen determinations.

Gradual consumption of the oxygen took place in those bottles which were incubated in the dark (Table VIII). In the light, oxygen was rapidly liberated, due to the photosynthetic activity of the diatom population in the enriched sea water; after 7 days, the nitrate disappeared completely; the phosphate was present in excess of the requirements of the diatoms; the oxygen increased by 4.62 c.c. per litre of water. When the bottles were now placed in the dark,

\section{Table VIII. Synthesis and Oxidation of Diatom MATERIAL IN ENRICHEd SEA WATER*}

\begin{tabular}{|c|c|c|c|c|c|}
\hline \multirow{3}{*}{\multicolumn{2}{|c|}{$\begin{array}{c}\text { Incubation of bottles, } \\
\text { days }\end{array}$}} & \multicolumn{3}{|c|}{ On basis of I litre of water } & \multirow[b]{4}{*}{$\begin{array}{l}\text { Bacteria in } \\
\text { I c.c. }\end{array}$} \\
\hline & & \multirow{3}{*}{$\begin{array}{l}\text { Oxygen } \\
\text { above }(+) \\
\text { or less }(-) \\
\text { than the } \\
\text { control } \\
\text { c.c. }\end{array}$} & \multicolumn{2}{|c|}{ Phosphate } & \\
\hline & & & \multirow{2}{*}{\multicolumn{2}{|c|}{$\begin{array}{c}\text { Regenerated } \\
\text { as a result } \\
\text { of incubation } \\
\text { in the dark } \\
\gamma / 1 .\end{array}$}} & \\
\hline Light & Dark & & & & \\
\hline 7 & - & +4.62 & 420 & - & $\mathrm{I} 45,000$ \\
\hline 7 & 2 & +3.54 & 500 & 80 & 72,000 \\
\hline 7 & II & $+\mathrm{I} \cdot 98$ & 460 & 40 & 6,000 \\
\hline I3 & - & +9.39 & 260 & - & 103,000 \\
\hline I3 & 5 & +8.37 & 310 & 50 & 120,000 \\
\hline 13 & I2 & +5.74 & 330 & 70 & 35,000 \\
\hline- & 7 & -0.30 & 890 & - & 30,000 \\
\hline- & I3 & -0.42 & 760 & - & 72,000 \\
\hline
\end{tabular}

* The nitrate nitrogen added and found in control water was $0.76 \mathrm{mg}$. per litre; it completely disappeared in the bottles incubated for 7 days in the light.

there was a reduction of $\mathrm{I} \cdot 08$ c.c. in the oxygen content per litre in 2 days, and of 2.64 c.c. in II days. When photosynthesis was allowed to proceed for I3 days, the oxygen content of the water increased by 9.39 c.c. per litre; incubation in darkness following this period resulted in a decrease of $\mathrm{I} \cdot 02$ c.c. in oxygen concentration in 5 days, and of 3.65 c.c. oxygen in 12 days. The consumption of phosphate in the light was $470(890-420) \gamma$ per litre in 7 days, and $500(760-260) \gamma$ in $\mathrm{I}_{3}$ days. When oxidation of the diatoms began, the phosphorus was regenerated as phosphate, but only very slowly. The gradual disappearance of the phosphate in the water kept in the dark was due either to its partial consumption or to its precipitation as insoluble phosphate, as a result of addition of iron, as ferric chloride.

Considerable variation was found among the individual bottles in the previous experiments. This may account for some of the discrepancies obtained in certain determinations. In order to check this, the results of another 
experiment are reported here. In this, all the determinations were made at least in duplicate and sometimes in triplicate; the analyses were also carried out at more frequent intervals (Table IX). Only one concentration of nitrate was used, namely $5 \mathrm{mg}$. $\mathrm{KNO}_{3}$ per litre. The maximum amount of photosynthesis, as measured by the oxygen liberated, was attained in 7 days; nitrate assimilation continued even after the maximum was attained. At that time, oxidation of the synthesized material seemed to coincide with assimilation. When photosynthesis was stopped, by incubating the bottles in the dark, rapid oxidation of the diatoms took place, especially at the 5-7 day periods when the diatom population in the water was carrying out its most active

\begin{tabular}{|c|c|c|c|c|c|c|}
\hline \multicolumn{2}{|c|}{$\begin{array}{l}\text { Incubation of bottles, } \\
\text { days }\end{array}$} & \multirow{2}{*}{$\begin{array}{c}\text { Oxygen } \\
\text { content } \\
\text { per litre } \\
\text { c.c. }\end{array}$} & \multirow{2}{*}{$\begin{array}{l}\text { Nitrate N } \\
\text { per litre } \\
\text { mg. }\end{array}$} & \multicolumn{2}{|c|}{ Phosphate $\gamma$ per litre } & \multirow{2}{*}{$\begin{array}{l}\text { Bacteria } \\
\text { in I c.c. }\end{array}$} \\
\hline Light & Dark & & & Left & Regenerated & \\
\hline 0 & 0 & $5 \cdot 38$ & 0.84 & 850 & - & 12,000 \\
\hline 3 & 0 & $7 \cdot 65$ & $0.4 \mathrm{I}$ & 700 & - & I82,000 \\
\hline 3 & 5 & 7.07 & & 750 & 50 & 31,000 \\
\hline 5 & 0 & $15 \cdot 18$ & O.II & 490 & & - \\
\hline 5 & 5 & $9.5 \mathrm{I}$ & 0.13 & 670 & 180 & - \\
\hline 7 & 0 & I $7 \cdot 47$ & 0.16 & 470 & $\overline{140}$ & $\begin{array}{r}132,000 \\
\text { I } 5,000\end{array}$ \\
\hline $\begin{array}{r}7 \\
10\end{array}$ & $\begin{array}{l}5 \\
0\end{array}$ & $\begin{array}{l}12 \cdot 27 \\
17 \cdot 42\end{array}$ & $\overline{0.03}$ & $\begin{array}{l}610 \\
340\end{array}$ & $\underline{140}$ & $\begin{array}{r}15,000 \\
126,000\end{array}$ \\
\hline ro & 5 & $\begin{array}{l}17.42 \\
12.62\end{array}$ & - & $\underline{340}$ & - & 28,000 \\
\hline I 2 & 0 & 17.66 & - & 340 & - & 42,000 \\
\hline I2 & 5 & 13.06 & - & - & - & 75,000 \\
\hline
\end{tabular}

photosynthesis. The ratio between nitrogen and phosphate assimilation, for the first three days of photosynthesis, was $\frac{0.43}{0.15}$ or $2.9: \mathrm{I}$, and for the 5 day period, $\frac{0.73}{0.36}$ or $2.0: \mathrm{I}$.

When the bacterial numbers are examined, it is found that the oxidation processes taking place in the freshly synthesized diatom cultures were not accompanied by any appreciable increase of bacteria. To be sure, there were more bacteria in the bottles in which photosynthesis took place. Nevertheless, the bacterial population, as determined by the plate method, remained comparatively limited, even with the large amounts of fresh diatom material undergoing active oxidation in the dark. Those bacteria that were found in the bottles grew very slowly on the plates and required at least 7 days' incubation for an adequate count. One must, therefore, conclude that bacteria do not play any important role in the oxidation of fresh diatom material.

A microscopic examination of the plankton, centrifuged after varying periods of photosynthesis, revealed the presence of large numbers of diatoms, including species of Nitzschia, Navicula, Rhizosolenia, and others. However, after the diatoms had undergone oxidation in the dark following photosynthesis, microscopic examination of the centrifuged or sedimented material revealed 
the presence of large numbers of Protozoa, especially certain types of amoebae, and ciliates, as well as flagellates, capable of feeding on diatoms. The bottles were also found to contain varying numbers of copepods. In the presence of such a large animal population, it seems highly probable that the effect of bacteria on the decomposition of the diatom constituents of the plankton was of minor importance. It is of interest to call attention to the suggestion of Lackey (I936) that Protozoa play an important role in the destruction of marine plant and animal residues, and also to the generally recognized role of the diatoms in the nutrition of copepods and other animal forms (Fuller \& Clarke, I936).

\section{DisCUSSION}

The results obtained in these investigations point definitely to the fact that dead diatoms in sea water are rapidly decomposed by bacteria. In the absence of sufficient available energy, a part of the phosphate regenerated in the process of decomposition may be immediately liberated into the sea water whereas the rest, which represents the greater portion of the phosphate, is incorporated into the bacterial protoplasm as it is synthesized. Usually, however, there is an initial decrease of the dissolved phosphate due to its rapid consumption by the bacteria. The decomposition of the diatoms is accompanied by a marked increase in the bacterial population. The bacterial numbers reach a peak in a short time and then drop rapidly to low and fairly constant levels. With the death and autolysis of the bacteria, phosphate is again rapidly regenerated. Through the agency of this phosphorus cycle almost two-thirds of the phosphorus present in the dead diatoms was found in the sea water within 132 hours. In the presence of an adequate supply of available energy, all of the phosphate originally found in the sea water and also that amount which was liberated in the decomposition of the diatoms was consumed by the rapidly multiplying bacteria. But it in turn was soon regenerated into the sea water as the bacteria died and underwent autolysis.

Living diatoms, however, were not attacked by the bacterial population of the sea water. Although a greater bacterial population was usually found in the water containing living diatoms than in the untreated sea water, this increase is of a much smaller order of magnitude than that attained by bacteria in the presence of readily decomposable organic substances, as glucose or amino acids. Whereas in the breakdown of copepod plankton, a distinct parallelism was found between oxygen consumption, bacterial multiplication and ammonia liberation, in the case of the diatom plankton, no such parallelism existed. Nitrogen was liberated at a very slow rate, and the bacteria increased only to a limited extent, as compared with their numbers in the free water; this limited increase might have been due to the feeding of the bacteria on substances excreted by the diatoms or upon some of the dying diatoms.

Neither was the oxidation of freshly synthesized diatom material accompanied by active bacterial multiplication. The consumption of oxygen under 
these conditions was due largely to the respiration of the diatoms themselves. It seems, therefore, that living diatoms, even when photosynthesis is excluded, possess considerable resistance to bacterial attack. They are gradually consumed, however, by the animal members of the plankton. This may further account for the fact that while the process of diatom breakdown is accompanied by oxygen consumption, it is not necessarily accompanied by a parallel increase in bacterial numbers.

The authors are indebted to Miss L. Lillick, for the identification of the diatoms, to Dr C. E. Renn, for assistance in the collection of the plankton, and to $\operatorname{Dr} M$. Hotchkiss for assistance in the determination of bacterial numbers.

\section{SUMMARY}

I. Dead marine diatom plankton was found to undergo rapid oxidation and decomposition when added to fresh sea water. This was measured by oxygen consumption, nitrogen liberation, phosphate regeneration and bacterial multiplication.

2. Living diatoms added to sea water and placed in the dark continued to absorb oxygen; they were rather resistant to bacterial attack.

3. Diatom-rich marine plankton also absorbed oxygen, while the phosphorus was gradually regenerated. The bacteria did not increase in numbers in correspondence with the oxidation of the fresh diatom material.

4. When sea water in which photosynthesis was allowed to proceed for varying periods of time was placed in the dark, rapid oxidation of the freshly synthesized material took place, as indicated by oxygen consumption and phosphate liberation. Although there was a greater number of bacteria in the water in which photosynthesis took place, the oxidation of the fresh diatom material was not accompanied by any large increase in bacteria; in fact a decrease in numbers was frequently observed.

5. When photosynthesis was stopped by placing the bottles in the dark, there was a marked increase in the numbers of Protozoa, notably various amoebae and ciliates, and also of copepods.

6. These results suggest that the animal forms may be largely responsible for the destruction of the living diatoms in the plankton. The role of bacteria in the regeneration of the nitrogen and phosphorus in the sea consists in the destruction of the dead diatoms as well as of the animal residues. 


\section{REFERENCES}

COOPER, L. H. N., I935. The rate of liberation of phosphate in sea water by the breakdown of plankton organisms. Fourn. Mar. Biol. Assoc., Vol. xx, pp. 197-202.

Fuller, J. L. \& Clarke, G. L., I936. Further experiments on the feeding of Calanus finmarchicus. Biol. Bull., Vol. 70, pp. 308-20.

Gran, H. H., I933. Studies on the biology and chemistry of the Gulf of Maine. II. Biol. Bull., Vol. 64, pp. I59-82.

LACKEY, J. B., I936. Occurrence and distribution of the marine protozoan species in the Woods Hole area. Biol. Bull., Vol. 70, pp. 264-78.

RenN, C. E., I937. Bacteria and the phosphorus cycle in the sea. Biol. Bull., Vol. 72, pp. I90-5.

WAKSMAN, S. A. \& CAREY, C. L., I935. Decomposition of organic matter in sea water by bacteria. II. Influence of addition of organic substances upon bacterial activities. Fourn. Bacter., Vol. 29, pp. 545-61.

Waksman, S. A., Carey, C. L. \& Reuszer, H. W., I933. Marine bacteria and their role in the cycle of life in the sea. I. Decomposition of marine plant and animal residues by bacteria. Biol. Bull., Vol. 65, pp. 57-79.

WaKsman, S. A. \& Hotchkiss, M., 1937. Viability of bacteria in sea water. Fourn. Bacter., Vol. 33, pp. 389-400.

WAKSMAN, S. A. \& RENN, C. E., I936. Decomposition of organic matter in sea water by bacteria. III. Factors influencing the rate of decomposition. Biol. Bull., Vol. 70 , pp. $472-83$. 